\title{
COMMUNICATIVE LANGUAGE TEACHING' AND ITS RELEVANCE TO THE LIBYAN ENGLISH LANGUAGE TEACHING CONTEXT
}

\author{
by \\ Khalil Jahbel \\ Universitas Negeri Malang \\ Alzytouna University Tarhouna Libya \\ enclavejung@gmail.com
}

\begin{abstract}
:
The main purpose of this paper is to investigate the relevance of the communicative language teaching (CLT) to the teaching English in Libyan context. Moreover, it was intended to highlight the historical perspective, features and principles of CLT, followed by an illustration and discussion of the description of the specific classroom context. Finally, after discussing all the elements that are pertaining to this approach, it concluded that CLT seems to be an appropriate approach that may remain on top of a variety -list of approaches, since it focuses on all the language aspects such as functional and grammatical elements and also its tasks imply working with real life situations.
\end{abstract}

Key Words: CLT, Historical, Approach, Libyan

\section{INTRODUCTION}

The growing need for good communication skills in English has created a great demand for English language teaching in all parts of the world. The majority of people today want to improve their ability of using English. Chances to learn English are available in many different ways such as through formal education, or other means of communication and the Internet. This has produced an incredible demand for quality language teaching. Second language learners want to be able to control English at a high level of accuracy and fluency. Consequently, a great need for a suitable teaching methodology has emerged.(Richard, 2001 p. 1). This essay aims to analyse and give a brief discussion of CLT , and to discuss its historic perspective ,with a brief illustration of its features, and also its relevance to the Libyan context.

\section{Historical perspective:}

Up the late 1960s traditional approaches were applied and in the 1970s , a reaction to those old methods (Audiolingualism and situational language teaching) began and soon spread around the world. The focus on grammar in language teaching and learning was questioned, since it was argued that language ability involved much 
more than grammatical competence. Although it was needed to produce grammatically correct sentences, but attention shifted to the knowledge and skills needed to use grammar and other aspects of language appropriately for different communicative purposes such as, making requests, giving advice, describing wishes and needs and so on. and due to the need in Europe to teach older people the language especially after many European countries had become independent. As a result of what has been mentioned above, a new approach emerged called ' communicative language teaching'. (Richards, J, c \& Rodgers, t 153-155) .

\section{DESCRIPTION AND FEATURES:}

One of the ways of understanding CLT is to know the meaning of the term 'communicative', and discussing the main features of this approach:

What I understand of CLT simply, is a way of teaching language to others like other methods, but according to different principles, and it mainly centres on communicating and interaction between learners. Harmer (2007,p.69), states that defining CLT is difficult since it consists of different approaches. It concerns different factors such as speaking skills and written grammar, moreover, it deals with special expressions that people can use in social occasions, so teachers of this approach can teach the learners how to speak appropriately in different contexts, and at the same time they insist on using these expressions in a grammatically accurate manner. Littlewoods (1981,p.1) states that ' One of the most characteristic features of communicative language teaching, is that it pays systematic attention to functional as well as structural aspects of language',

It may mean a set of rules such as, the way is language taught to students, and the appropriate actions that should be performed during the learning process in the learning setting, and participants' responsibility in the classroom setting. Since the definition of the approach is as some of connected assumptions that deal with the nature of language teaching and learning, so people who support the CLT consider it as an approach rather than a method, which invents some procedures for teaching the four skills.(Richards \& Rodgers,2001) . CLT aims to teach communicative competence, which means the techniques of using the right language for a variety of purposes and at the appropriate time. For example, informal and formal language of speech, and as well for all the language skills.(Richards and Rodgers, 2001,p.155). (Yule, 2006,p.166) states that " functions of language (what it is used for) should be 
emphasised rather than the forms of the language (correct grammatical or phonological structures). Moreover, using varieties of communication strategies." Another consideration of the approach (CLT) is the technique or the method through which learners learn language . (Yule,2006,p. 162) states that learning language has two factors, either to learn language in a foreign language setting or in a second language setting. The former indicates learning language in a society where the target language is not spoken. For example, learning English language in Libya, where the only language spoken is Arabic , however, the latter indicates learning language in a society where English language is spoken. For example, learning English language in Malta or Nigeria.

Communicative language learning has different distinctive characteristics that cause it to be used more than the other approaches such as, it considers language as a way of communicating between at least two people, moreover, it considers language as a mutually supporting an arrangement that includes the four skills of learning. Another consideration, which is stating that learning process, occurs while the exits of authentic communication is engaged, in other words, when interaction and intervention are required, and also when language and context are real. In CLT, learners should be responsible in the learning process, and they must use their second language if they want a successful outcome.

Supporting the discussions above, Nunan (1991) states that CLT is usually defined as a broad approach to teaching rather than a teaching method with a clearly defined set of classroom practices. In addition, he defines it as of general principles or features:

1. An emphasis on learning to communicate through interaction in the target language.

2. The introduction of authentic texts into the learning situation.

3. The provision of opportunities for learners to focus, not only on language but also on the (learning management) learning process.

4. An enhancement of the learner's own personal experiences as important contributing elements to classroom learning.

5. An attempt to link classroom language learning with language activities outside the classroom.

A brief description of the specific classroom context: 
As the Libyan authorities noticed that English has become an international language, so teaching English as a foreign language has become a compulsory part of the curricular set by the educational authorities in Libya. The aim behind that is enabling students to understand, speak and use the language in all its manifestation. As a result, English was introduced to the 5 th and $6^{\text {th }}$ class in primary school in 2006/2007. Right now, English is a compulsory course from the 5th primary class up to the 3rd secondary class. The number of periods for teaching English is 4 periods per week, each period lasts for 45 minutes. The school-year is divided into two terms, each lasts for four months. In each term, students sit for a mid-term exam, and sit for a final exam. (Frino; 2008,p. 6) states that "the books have been written with the specific needs of Libyan students in mind. This means that the contexts and topics in which the language is presented have been chosen to draw upon their knowledge and experience of the world, as well as their personal interests. The material in the series is built accumulatively in a way that students should have been mastering the previous part of the series. The language is carefully graded and manipulated through presenting different topics that students have in other school subjects such as geography, science, history, environment, achievements and technology. The course is composed of four parts; the course book, the workbook, CD, and the Teacher Book.

The course books are divided into units in which each of them includes some lessons starting with introducing and revising the target language through some exercises in the course book and the workbook. The course depends heavily on the students' performance and their activity in the class either personally or in groups. The tasks include speaking, listening, reading, writing, role-playing, and sometimes playing games. The aim behind that is to provide the student with an ability to experience the four skills of language. Therefore, teachers have to apply CLT in class and use materials and facilities to achieve better results.

\section{Critical Discussion of Relevance to the Libyan Context:}

If we consider the relevance of CLT to the Libyan context, it should be mentioned that, due to globalization, which has turned the world into one village, and to the recent changes in different aspects of life in all over the world, and since the new technologies are in English language, so most countries including Libya have imposed English in their school curriculum, to be taught in all education stages, starting from year five in primary stage till university stage. 
Most Libyan students want to cope with the progress that the world has been experiencing these days, especially after the security council raised the embargo on Libya , and due to the new arrangements which were set out by the government towards tourism, which a lot of people will need to be perfect in different languages especially English language . Hence, they should command competence in all language skills. Teachers have to apply different methods in order to achieve their target, as Libyan students study English language in different stages which are ,primary, preparatory, secondary and higher education (university) and at the end of each term there has to be a written exam in English language as the other subjects. Students have either integrative motivation or instrumental motivation. They study English language in order to pass their exam to reach the next stage until they graduate, what is more to get good job in the future since the opportunities of getting a well paid job is to be perfect in English language at most of the companies; for this reason many students are keen to study it, moreover, many students these days prefer to study abroad to improve their qualification , and that entails a command in English language. They also need to be able to communicate with others outside of the classroom, and this requires a large amount of practice within the classroom. For these reasons, teachers should apply the most appropriate method ,that may suits students' needs and their attitudes towards the language, which is seem to be the communicative language teaching. It can play a significant role in improving their speaking ability, and moreover, prepare them to use their acquired language in everyday conversations. The CLT approach tries to involve students in practical use of their language in important functions.(Richards \& Rodgers, 2001,p.159). On the other hand as there are Libyan students have benefited from it there are students who find it difficult to interact with each other and with the outer world as well due to their weak background in English language and also because Libya is not a L2 speaking country, since the students had no chance to practice their L2 language outside the classroom. In the past, students studied the language without any techniques that seem to be the best way to facilitate the learning process .for example, the Grammar Translation Method, an old method which mainly focuses on vocabulary and grammar, however, it gives less attention to the most important skills such as speaking and listening.(Larsen-Freeman,2000,p.18), which Libyan students need especially after Libya has opened its borders to the external world, particularly, the external investments and tourism, students need to command their L2 more than 
before, and teachers have to apply all the techniques in classroom. Each development has its impact on understanding the language. For example, students' autonomy (enabling them to be the doers rather than the recipients of learning action. (Harmer,2007,p.394). It has significant role in the process of learning that may help students to feel more self-confident, which leads to make them do some activities by themselves, i.e., without the help of the teacher. Harmer (2007), says in this issue that '"we should encourage students to do some of the work for themselves, discovering how language works rather than being given information about language construction on a plate'. The teacher should be aware enough in case students get confused of being responsible for their way of learning, moreover, they should encourage them to develop their own strategies, so that they can compensate the short hours of classroom lessons. ( p.79-395).

\section{CONCLUSION}

By studying CLT in more detail, it appears to be the most appropriate approach that may remain on top of a variety -list of approaches, since its instructional principles involve different classroom activities that are performed in a communicative process, moreover, it focuses on all the language aspects such as functional and grammatical elements and also its tasks imply working with real life situations which Libyan students need to communicate with foreigners outside of the classroom, in addition it will be appropriate for those who intend to become interpreters in the future.

\section{BIOPROFILE}

Khalil Jahbel is an assistant lecturer of English language. Teaching English to speakers of other languages at the English department in the college of languages Alzytouna University-Tarhouna Libya. He graduated from University of Sunderland UK, with an MA in TESOL in 2011. His research interests include Language Learning and Teaching. Corresponding author: enclavejung@gmail.com 


\section{REFERENCES:}

Frino, Lucy, et al (2008). English for Libya, Preparatory 3, teacher's Book, general People's Committee for Education and Scientific Research, Education and Curricula Center, 1 st ed.

Harmer, J. (2007). The Practice of English Language Teaching. $4^{\text {th }}$ ed. Essex: Longman.

Larsen-freeman,D.(2000).Techniques and Principles in Language Teaching, $2^{\text {nd }}$ Ed, oxford university press.

Littlewoods, W. (1981) . Communicative language teaching: An introduction. Cambridge: Cambridge University Press.

Nunan, D. \& Lockwood, J. (1991). The Australian English course: Task- based English for post-beginners. Cambridge: Cambridge University Press.

Richards,J.C. \& Rodgers, T (2001) . Approaches and methods in language teaching. second edition, cambridge university press.

Richards, J, C. Communicative Language Teaching Today. www.professorjackrichards.com

Yule,G. (2006) .The study of language, third edition. Cambridge university press. 